\title{
Ethnobotanical Euphorbian plants of North Maharashtra Region
}

\author{
Yuvraj D. Adsul ${ }^{1}$, Raghunath T. Mahajan ${ }^{2}$ and Shamkant B. Badgujar ${ }^{2}$ \\ ${ }^{1}$ Department of Biotechnology, SSVP's, Dr. P.R. Ghogrey Science College, Dhule 424001, Maharashtra, India \\ ${ }^{2}$ Department of Biotechnology, Moolji Jaitha College, Jalgaon, 425 002, Maharashtra
}

\begin{abstract}
Euphorbiaceae is among the large flowering plant families consisting of a wide variety of vegetative forms. Some of which plants are of great importance, It is need to explore traditional medicinal knowledge of plant materials belonging to various genera of Euphorbiaceae available in North Maharashtra State. Plants have always been the source of food, medicine and other necessities of life since the origin of human being. Plant containing ethnomedicinal properties have been known and used in some forms or other tribal communities of Satpuda region. These tribal have their own system of Ethnomedicine for the treatment of different ailments. In the course of survey useful Euphorbian plants of Satpuda, 34 medicinal plants belonging to 18 genus is documented. This article reports their botanical identity, family name, local language name part used preparations and doses, if any. It is observed that tribes of this region uses various Euphorbian plant in the form of decoction, infusion, extract, paste, powder etc. Thus the knowledge area of this region with respect to ethnomedicine would be useful for botanist, pharmacologist and phytochemist for further explorations. It is concluded that the family is a good starting point for the search for plant-based medicines.
\end{abstract}

Keywords: Ethnomedicine, Tribals, Satpuda region, Euphorbian medicinal plant.

\section{Introduction}

The family Euphorbiaceae is one of the largest families of flowering plants it composed of over 300 genera and 8,000 species. The family is very diverse in range, composed of all sorts of plants ranging from large woody trees through climbing habit to simple weed that grows prostrate to the ground. The member of Euphorbiaceae are widely distributed all around the world, many family members are inhabitants of tropical climates surviving hot dry desert condition while other are rainforest trees and herbs. The family consists of species of great economic importance like Ricinus communis (Castor oil plant) Manihot esculenta and Hevea brasiliensis. Euphorbiaceae is complex family with a lot of research potential ${ }^{1}$.

Complexity in habitat range and variability in morphology and genetics has made Euphorbiaceae classification difficult. Homogenous families have their classification based on simple, unique characteristics that cut across the family, eg. monocotyledony and parallel venation for family poaceae. In the case of Euphorbiaceae, there appears to be no particular and easily observable feature that can be used for its classification.The enumeration of several anatomic features like wood structure, laticifer type, trichomes and nature of stomata as being important for family classification, while other like pollen nuclear, exine structures, type of pollination and inflorescence types are important for classifying genera, tribes and subfamilies ${ }^{2}$.

Ethnobotany deals with studies among the tribals and rural people for recording their unique knowledge about plant wealth and for search of new sources of herbal drugs edible plants and other aspect of plants. Plants medicines are regarded as highly important in the lives of our ancestors plants the basis for life on earth have been widely used as a source of medicine by man since ancient times ${ }^{3}$. Most of the people depending on traditional medicine live in developing countries and they realy mainly on traditional herbal medicine to meet their primary health care needs. The science of ethnobotany is concerned with the relationship between man and vegetation involving man's dependence upon vegetation as well as tremendous influence man has had on vegetatin. Recently, Tripathi and Srivastava (2010) reported important of ethnomedicinal flora use in dermatological problem where they mentioned 7 genera with 11 species of Euphorbiaceae family ${ }^{4}$.

The species of Euphorbiaceae have been used by local population of many part of countries in folk medicines as remedies against several diseases and complaints such as cancer, diabetes, diarrhoea, heart diseases, hemorrhages, hepatitis, Jaundice, malaria, ophthalmic diseases, rheumatism and scabies etc. In India following genera of Euphorbiaceae are reported as medicinal plants. Acalypha, Bridelia, Chrozophora, Jatropha, Mallotus, Phyllanthus, Baliospermum, Cicca acida, Euphorbia nerifolia, Euphorbia thymifolia, Jatropha gossypifolia, Ricinus communis. ${ }^{5}$ A part from these many of Euphorbiaceae members have been used in traditional folk medicines such as Acalypha indica for rheumatic arthritis, Phyllanthus fratarnus for treatment of leprosy. The present study is the attempt to prepare the survey, documentation and enumeration of Euphorbian medicinal plants in the study area. ${ }^{6}$ 


\section{Materials and Methods}

Plant materials belonging to various genera of the Euphorbiaceae, readily available in North Maharashtra region were collected from Dhule, Nandurbar and Jalgaon districts. Specimens were satisfactorily identified and confirmed with the help of the herbarium at Department of Botany. S.S.V.P.S. Dr. P.R. Ghogrey Science College Dhule. The survey was conducted according to the method evolved and adopted by different ethnobotanists. The methodology used by various investigators is based on the emphasis of the nature of information sought.

\section{Location and study area}

Geographically Maharashtra is located in the center of North and South side of India and it is the $3^{\text {rd }}$ largest state with a geographical area $307690 \mathrm{Sq}$. $\mathrm{kms}$ and lies between $16^{\circ} 40^{\prime}$ to $22^{\circ} 10^{\prime} \mathrm{N}$ latitude and $72^{0} 56^{\prime}$ to $80^{\circ} 09^{\prime}$ E longitude. Western border of it is linked with Arabian sea having 825 sq. kms length. 750 sq. kms long Eastern side is connected to Madhya Pradesh (MP), 1875 sq. kms long southern border it attached to Andhra Pradesh and Karnataka and 1725 sq. kms long Northern border is linked with Gujrat an Madhya Pradesh. Maharashtra is distributed in to 35 districts ad 303 tahsils. There are four different region of Maharashtra Viz, Khandesh. Marathwada, Vidharbha and Kokan, Khandesh region of Maharashtra was divided into two parts since 1906 i.e. West Khandesh and East Khandesh which were, later on renamed after the district headquarters as Dhule and Jalgaon district respectively. (Mahajan and Badgujar 2008)Later on Dhule was divided into two districts i.e. Nandurbar and Dhule, on 01 Jul 1998. Nandurbar district is bounded by Dhule in South, Gujrat and Madhya Pradesh in West and North Madhya Pradesh and Dhule in Eastern. ${ }^{16}$

\section{Methods}

An ethnomedicinal survey was conducted in surrounding areas of Satpuda M.S. This area is inhibited by Bhills, Gavits, Kokanis, Padvis, Tadvis, Valvis, Pawaras etc. Regular visits were made during the period 2008-2010. The information was collected from local traditional healers and aboriginal people of Satpuda, considering two different types of observation viz ethnobotanical and household survey related to quantification of plant products consumed or gathered. Criteria adopted for present study include i) Interview, ii) inventory. Former includes asking questions about ethanobotanical application of Euphorbian plant for different purposes such as medicine, food, fuel, folder etc. Simultaneously recording the common names of plant, forest visits with ethnobotanical knowledge provider tribe or informants for identification of specific plant was also made. The latter involves collection of plant specimen, making herbarium and interviewing the informants for names and uses of corresponding plant specimen. Above both approaches were repeated with knowledgeable tribal heads, traditional healers, elders, bhagats, buwas etc. in to the forest and information was verified in different seasons and surrounding area of visited villages of particular district. The collected data has been compared with recent literatures The fresh specimen of the plants were collected and identified taxonomically by the experts matching with authentic herbarium books on flora ( Kirtikar and Basu 1995) and photographs. ${ }^{8}$

\section{Species enumeration}

The plants are arranged alphabetically as per their botanical names. These are followed by the family names and then by their local names and plant part used along with the method of application described.

Table 1 : Medicinally important Euphorbiaceae plants belonging to Northern region of Maharashtra

\begin{tabular}{|c|l|l|l|l|l|l|l|}
\hline $\begin{array}{c}\text { Sr. } \\
\text { No. }\end{array}$ & $\begin{array}{c}\text { Botanical } \\
\text { Name } \\
\text { (Voucher } \\
\text { specimen) }\end{array}$ & $\begin{array}{c}\text { Common } \\
\text { name }\end{array}$ & $\begin{array}{c}\text { Life } \\
\text { form }\end{array}$ & $\begin{array}{c}\text { Period of Fl } \\
\text { and Fr }\end{array}$ & Habitat & Part \\
used
\end{tabular}




\begin{tabular}{|c|c|c|c|c|c|c|c|}
\hline 04 & $\begin{array}{l}\text { Acalypha } \\
\text { wilkesiana } \\
\text { Muell.-rg.(EP4) }\end{array}$ & Copper leaf & Shrub & $\begin{array}{l}\text { Throughout } \\
\text { year }\end{array}$ & $\begin{array}{l}\text { Grow in gardens for } \\
\text { its highly ornamental } \\
\text { leaves. }\end{array}$ & $\begin{array}{l}\text { WP } \\
\text { LF }\end{array}$ & $\begin{array}{l}\text { The expressed juice or boiled } \\
\text { decoction is used for the } \\
\text { treatment of gastrointestinal } \\
\text { disorders and fungal skin } \\
\text { infections. The leaves of this } \\
\text { plant are eaten as vegetables in } \\
\text { the management of hypertension. } \\
16\end{array}$ \\
\hline 05 & $\begin{array}{l}\text { Baliospermum } \\
\text { raziana Keshav } \\
(\text { EP5 })\end{array}$ & $\begin{array}{l}\text { Dathi, } \\
\text { Lepkyo }\end{array}$ & Shrub & $\begin{array}{l}\text { September- } \\
\text { December }\end{array}$ & $\begin{array}{l}\text { In shady habitats, } \\
\text { and cleared forest } \\
\text { areas along the } \\
\text { roads and the bank } \\
\text { of nallas etc. }\end{array}$ & $\begin{array}{l}\text { LT, } \\
\text { RT }\end{array}$ & $\begin{array}{l}\text { Latex is applied externally on } \\
\text { skin diseases; root is used in } \\
\text { constipation ( } 1-2 \text { gm roots are } \\
\text { crushed and soaked in water-this } \\
\text { water is administered as a single } \\
\text { does against constipation) } 17\end{array}$ \\
\hline 06 & $\begin{array}{lr}\text { Bridelia } & \text { airy- } \\
\text { shawii } & \text { P.T.Li } \\
(\text { EP6) } & \end{array}$ & $\begin{array}{l}\text { Asan, Ahani, } \\
\text { Agan, Ahan }\end{array}$ & Tree & $\begin{array}{l}\text { July- } \\
\text { December }\end{array}$ & $\begin{array}{l}\text { Frequently found on } \\
\text { hill slopes }\end{array}$ & $\begin{array}{l}\text { FT, } \\
\text { SB }\end{array}$ & $\begin{array}{l}\text { Ripe fruits are edible; bark } \\
\text { powder is used diabetic and a } \\
\text { powerful tonic for reducing the } \\
\text { body weight. } 1\end{array}$ \\
\hline 07 & $\begin{array}{l}\text { Chrozophora } \\
\text { prostrate Dalz. } \\
(E P 7)\end{array}$ & $\begin{array}{l}\text { Betha, } \\
\text { Okharad, } \\
\text { Unhali }\end{array}$ & Herb & $\begin{array}{l}\text { Almost } \\
\text { Throughout } \\
\text { year }\end{array}$ & $\begin{array}{l}\text { In moist rocky and } \\
\text { sandy beds of } \\
\text { nallas, also a weed } \\
\text { in cultivated fields }\end{array}$ & $\begin{array}{l}\text { RT, } \\
\text { SD }\end{array}$ & $\begin{array}{l}\text { Decoction of roots is given in } \\
\text { cough to children ( } 10 \text { years old), } \\
\text { Seed: Purgative, the ash of root is } \\
\text { given early in the morning daily } \\
\text { with warm cow milk in asthma. } 6\end{array}$ \\
\hline 08 & $\begin{array}{l}\text { Chrozophora } \\
\text { rottleri (Geis.) } \\
\text { A. Juss.(EP8) }\end{array}$ & Unhali & Herb & $\begin{array}{l}\text { December - } \\
\text { February }\end{array}$ & $\begin{array}{l}\text { Weed in cultivated } \\
\text { fields, also in } \\
\text { wastelands, river } \\
\text { sides etc. }\end{array}$ & WP & $\begin{array}{l}\text { Plant has emetic, drastic and } \\
\text { corrosive properties, seeds are } \\
\text { used as a cathartic. } 8\end{array}$ \\
\hline 09 & $\begin{array}{l}\text { Cicca acida }(\text { L.) } \\
\text { Merr. }(\text { EP } 9)\end{array}$ & Rai-awala & Tree & $\begin{array}{l}\text { October - } \\
\text { March }\end{array}$ & $\begin{array}{l}\text { Cultivated in the } \\
\text { gardens }\end{array}$ & FT & $\begin{array}{l}\text { Remove dandruff, cure night } \\
\text { blindness, anti vomting } 10\end{array}$ \\
\hline 10 & $\begin{array}{l}\text { Cleidion } \\
\text { spiciflorum } \\
\text { (Burm.f.)Merr } \\
\text { (EP10) }\end{array}$ & Mahadi & Shrub & April-June & $\begin{array}{l}\text { Occasional in hilly } \\
\text { forest area }\end{array}$ & $\begin{array}{l}\mathrm{SD} \\
\mathrm{LE}\end{array}$ & $\begin{array}{l}\text { Aerial part is edible, sweet; } \\
\text { decoction of the leaves will } \\
\text { produce abortion } 15\end{array}$ \\
\hline 11 & $\begin{array}{l}\text { Codiaeum } \\
\text { variegatum (L.) } \\
\text { Juss.(EP11) }\end{array}$ & Croton & Shrub & $\begin{array}{l}\text { Almost } \\
\text { Throughout } \\
\text { year }\end{array}$ & $\begin{array}{l}\text { Cultivated in the } \\
\text { gardens for } \\
\text { ornamental purpose }\end{array}$ & LE & $\begin{array}{l}\text { Decoction of crushed leaves for } \\
\text { diarrhoea. Sap of leaves mixed } \\
\text { with coconut milk used for } \\
\text { sphylitic lesions. Leaves, for } \\
\text { antibacterial uses. } 16\end{array}$ \\
\hline 12 & $\begin{array}{l}\text { Croton } \\
\text { bonplandianum } \\
\text { Baill(EP12) }\end{array}$ & Putri & Herb & $\begin{array}{l}\text { Almost } \\
\text { Throughout } \\
\text { year }\end{array}$ & $\begin{array}{lr}\text { Naturalized } & \text { in } \\
\text { wastelands } & \text { along } \\
\text { roadside, } & \text { river } \\
\text { banks, railway lines } \\
\text { etc. }\end{array}$ & WP & $\begin{array}{l}\text { Control scabies, catarrh, } \\
\text { bronchitis \& asthma } 17\end{array}$ \\
\hline 13 & $\begin{array}{l}\text { Emblica } \\
\text { officinalis } \\
\text { Gaertn(EP13) }\end{array}$ & $\begin{array}{l}\text { Awala, } \\
\text { Amala, } \\
\text { Borbhajia } \\
\text { wala }\end{array}$ & Tree & $\begin{array}{l}\text { February- } \\
\text { August }\end{array}$ & $\begin{array}{l}\text { Occasional in hilly } \\
\text { forest area and also } \\
\text { planted }\end{array}$ & FT & Fruits are edible 1 \\
\hline 14 & $\begin{array}{l}\text { Euphorbia } \\
\text { clarkeana } \\
\text { Hook.f. (EP14) }\end{array}$ & & Herb & $\begin{array}{l}\text { August- } \\
\text { November }\end{array}$ & $\begin{array}{l}\text { Occasional in open } \\
\text { forest among } \\
\text { grasses }\end{array}$ & WP & $\begin{array}{l}\text { It is used to cure spermatorrhoea } \\
\text { and mouth blister } 6\end{array}$ \\
\hline 15 & $\begin{array}{l}\text { Euphorbia } \\
\text { cyathophora } \\
\text { Murr.(EP15) }\end{array}$ & Dudhali & Herb & $\begin{array}{l}\text { September- } \\
\text { March }\end{array}$ & $\begin{array}{l}\text { Mostly ornamental } \\
\text { and naturalized }\end{array}$ & WP & Useful as galactagogue 8 \\
\hline 16. & $\begin{array}{l}\text { Euphorbia hirta } \\
\text { L.(EP16) }\end{array}$ & Dudhi & Herb & $\begin{array}{l}\text { Almost } \\
\text { throughout } \\
\text { year }\end{array}$ & $\begin{array}{l}\text { Common weed in } \\
\text { different habitats }\end{array}$ & WP & $\begin{array}{l}\text { Urinary disorders, itches, } \\
\text { gonorrhoea Remove warts Cure } \\
\text { scabies (Skin diseases), burns, } \\
\text { antiseptic, antidysentric, } \\
\text { antidiarrhoea Plant juice is used } \\
\text { colic trouble, dysentery, } \\
\text { urinogenital diseases } 15\end{array}$ \\
\hline 17. & $\begin{array}{l}\text { Euphorbia } \\
\text { indica Lamk. } \\
\text { (EP17) }\end{array}$ & & Herb & $\begin{array}{l}\text { August- } \\
\text { December }\end{array}$ & $\begin{array}{l}\text { Common in waste } \\
\text { places and as a } \\
\text { weed in cultivated } \\
\text { fields }\end{array}$ & WP & $\begin{array}{l}\text { Whole plant is used as Ringworm } \\
\text { disease } 16\end{array}$ \\
\hline
\end{tabular}




\begin{tabular}{|c|c|c|c|c|c|c|c|}
\hline 18. & $\begin{array}{l}\text { Euphorbia milii } \\
\text { Desmoul. } \\
\text { (EP18) }\end{array}$ & Christ plant & Shrub & $\begin{array}{l}\text { Usually } \\
\text { March, May, } \\
\text { sometimes } \\
\text { Throughout } \\
\text { year }\end{array}$ & $\begin{array}{l}\text { Cultivated in the } \\
\text { gardens }\end{array}$ & LX & Latex is applied to treat sprain 1 \\
\hline 19. & $\begin{array}{l}\text { Euphorbia } \\
\text { nerifolia L. } \\
\text { (EP19) }\end{array}$ & $\begin{array}{l}\text { Sabar, } \\
\text { Sabari, } \\
\text { Sabar-Kand }\end{array}$ & Shrub & March-June & $\begin{array}{l}\text { Wild in hilly open } \\
\text { forest }\end{array}$ & RT & $\begin{array}{l}\text { A succus compounded of equal } \\
\text { parts of the juice and simple } \\
\text { syrup is said to be used for giving } \\
\text { relief in asthma } 4\end{array}$ \\
\hline 20. & $\begin{array}{l}\text { Euphorbia } \\
\text { nivulia Buch. - } \\
\text { Ham(EP2O). }\end{array}$ & Sabar & Shrub & March-June & $\begin{array}{l}\text { Wild on dry and } \\
\text { rocky regions }\end{array}$ & RT & Used in dropsy 17 \\
\hline 21. & $\begin{array}{l}\text { Euphorbia } \\
\text { pulcherrima } \\
\text { Willd.(EP21) }\end{array}$ & Lal-patta & Shrub & $\begin{array}{l}\text { November- } \\
\text { February }\end{array}$ & $\begin{array}{l}\text { Panted in gardens } \\
\text { for ornamental } \\
\text { floral-leaves }\end{array}$ & LE & Cure rheumatic pain 8 \\
\hline 22. & $\begin{array}{l}\text { Euphorbia } \\
\text { thymifolia L } \\
\text { (EP22). }\end{array}$ & Dudhi & Herb & $\begin{array}{l}\text { Usually } \\
\text { Throughout } \\
\text { year }\end{array}$ & $\begin{array}{l}\text { Weed in cultivated } \\
\text { fields }\end{array}$ & $\begin{array}{l}\text { RT, } \\
\text { LX, } \\
\text { WP }\end{array}$ & $\begin{array}{l}\text { Relieve joint pains, } \\
\text { antiinflammtory agent, applied } \\
\text { on bone dislocation of animals } \\
\text { Antidote for snake bie, } \\
\text { astringent, antihelmatic, againest } \\
\text { ring worm Laxative for children } \\
5\end{array}$ \\
\hline 23. & $\begin{array}{l}\text { Euphorbia } \\
\text { tirucalli L } \\
\text { (EP23) }\end{array}$ & $\begin{array}{l}\text { Thor, } \\
\text { Thorya, Sher }\end{array}$ & Tree & $\begin{array}{l}\text { Very rarely } \\
\text { flowers, fruits } \\
\text { not seen }\end{array}$ & As a hedge plant & $\begin{array}{l}\text { LX, } \\
\text { SB }\end{array}$ & $\begin{array}{l}\text { Latex applied extermally on } \\
\text { warts. Stem bark is used for } \\
\text { gastralgia } 8\end{array}$ \\
\hline 24. & $\begin{array}{l}\text { Jatropha curcas } \\
L(E P 24) \text {. }\end{array}$ & $\begin{array}{l}\text { Mogali } \\
\text { erand, } \\
\text { Ratanda }\end{array}$ & Shrub & $\begin{array}{l}\text { Almost } \\
\text { Throughout } \\
\text { year }\end{array}$ & $\begin{array}{l}\text { Planted in hedges } \\
\text { and also naturalized } \\
\text { in wastelands near } \\
\text { villages }\end{array}$ & $\begin{array}{l}\text { LX, } \\
\text { SB }\end{array}$ & $\begin{array}{l}\text { Bark is Used as a fish poison, } \\
\text { Latex Strongly inhibits the } \\
\text { watermelon mosaic virus Latex is } \\
\text { applied to treat boils and pimples. } \\
10\end{array}$ \\
\hline 25. & $\begin{array}{l}\text { Jatropha } \\
\text { gossypifolia L. } \\
\text { (EP25) }\end{array}$ & $\begin{array}{l}\text { Chandrajyot, } \\
\text { Chandre }\end{array}$ & Shrub & $\begin{array}{l}\text { Almost } \\
\text { Throughout } \\
\text { year }\end{array}$ & $\begin{array}{l}\text { Naturalized in } \\
\text { wastelands near } \\
\text { villages, along } \\
\text { nallas, rivers, } \\
\text { railway lines etc. }\end{array}$ & $\begin{array}{l}\mathrm{SD} \\
\mathrm{SB}\end{array}$ & $\begin{array}{l}\text { Seed oil is externally applied in } \\
\text { rheumatism, whereas decoction } \\
\text { of root is taken orally for } \\
\text { abdominal inflammation. A } \\
\text { decoction of the bark is used as } \\
\text { an emmenagogue. Seed oil is } \\
\text { used in skin diseases, Seeds are } \\
\text { drastic purgative and emetic, } \\
\text { Regular brushing with the twigs } \\
\text { keeps the teeth and gum disease } \\
\text { free and cures tooth-ache } 16\end{array}$ \\
\hline 26. & $\begin{array}{l}\text { Kirganelia } \\
\text { reticulate } \\
\text { (Poir.) Baill. } \\
(\text { EP26) }\end{array}$ & $\begin{array}{l}\text { Kali- } \\
\text { kumhuni, } \\
\text { pichrundi }\end{array}$ & Shrub & $\begin{array}{l}\text { August- } \\
\text { December }\end{array}$ & $\begin{array}{l}\text { On the edges of } \\
\text { fields and in } \\
\text { wastelands }\end{array}$ & FT & $\begin{array}{l}\text { Ripe fruits are edible and cure } \\
\text { skin diseases. } 12\end{array}$ \\
\hline 27. & $\begin{array}{l}\text { Mallotus } \\
\text { philippensis } \\
\text { (Lamk.) Muell.- } \\
\text { Arg.(27) }\end{array}$ & $\begin{array}{l}\text { Madari, } \\
\text { Shendrya, } \\
\text { Hendra }\end{array}$ & Tree & $\begin{array}{l}\text { December- } \\
\text { March }\end{array}$ & $\begin{array}{l}\text { Frequently in hilly } \\
\text { forest tracts }\end{array}$ & FT & $\begin{array}{l}\text { Hair of fruits used for the } \\
\text { treatment of tapeworm } \\
\text { infestation, in scabies, ringworm, } \\
\text { herpes etc. } 16\end{array}$ \\
\hline 28. & $\begin{array}{l}\text { Micrococca } \\
\text { mercurialis }(L) \\
\text { Benth. }(\text { EP28) }\end{array}$ & Garari & Herb & $\begin{array}{l}\text { August- } \\
\text { October }\end{array}$ & $\begin{array}{l}\text { Rare, in moist shady } \\
\text { habitats on gravelly } \\
\text { hilly slopes }\end{array}$ & WP & $\begin{array}{l}\text { The plant is used to treat children } \\
\text { with fever and the plant-sap is } \\
\text { instilled into the nose, eyes or } \\
\text { ears to treat headache, filariasis } \\
\text { of the eye or otitis, respectively } \\
17\end{array}$ \\
\hline 29. & $\begin{array}{l}\text { Pedilanthus } \\
\text { tithymaloides } \\
\text { (L.) } \\
\text { Poit.(EP29)) }\end{array}$ & $\begin{array}{l}\text { Vilayatisher, } \\
\text { Vilayatithor }\end{array}$ & Shrub & March-May & $\begin{array}{l}\text { Planted as hedge in } \\
\text { garden and around } \\
\text { bunglows }\end{array}$ & $\begin{array}{l}\text { RT, } \\
\text { LX }\end{array}$ & $\begin{array}{l}\text { Root along with the bark of } \\
\text { Moringa oleifera is pounded } \\
\text { together and administered after } \\
\text { menstruation to develop } \\
\text { permanent sterility in female. } \\
\text { Root is also a powerful emetic. } \\
\text { The latex has emetic, irritant and } \\
\text { caustic properties; used in } \\
\text { venereal troubles, also applied to } \\
\text { warts and leucoderma patches } 16\end{array}$ \\
\hline
\end{tabular}


Ethnobotanical Euphorbian plants of North Maharashtra Region

\begin{tabular}{|c|c|c|c|c|c|c|c|}
\hline 30. & $\begin{array}{l}\text { Phyllanthus } \\
\text { amarus } \\
\text { Schumach \& } \\
\text { Thonn (EP30). }\end{array}$ & Bhui awala & Herb & $\begin{array}{l}\text { August- } \\
\text { December }\end{array}$ & $\begin{array}{l}\text { Common in wet } \\
\text { localities and } \\
\text { cultivated fields }\end{array}$ & WP & $\begin{array}{l}\text { It is good galactagogue for goats } \\
\text { and sheep } 1\end{array}$ \\
\hline 31. & $\begin{array}{l}\text { Phyllanthus } \\
\text { maderaspatensi } \\
\text { s L.(EP31) }\end{array}$ & Ranavati & Herb & $\begin{array}{l}\text { August- } \\
\text { November }\end{array}$ & $\begin{array}{l}\text { Common in wet } \\
\text { localities and } \\
\text { cultivated fields }\end{array}$ & LE & $\begin{array}{l}\text { An infusion of leaves is used in } \\
\text { headache } 6\end{array}$ \\
\hline 32. & $\begin{array}{l}\text { Phyllanthus } \\
\text { urinaria L. } \\
\text { (EP32) }\end{array}$ & $\begin{array}{l}\text { Erandi, } \\
\text { Erand, } \\
\text { Diwali, } \\
\text { Diwegi }\end{array}$ & Tree & $\begin{array}{l}\text { Almost } \\
\text { Throughout } \\
\text { year }\end{array}$ & $\begin{array}{l}\text { Common in open } \\
\text { fields and in rock } \\
\text { places }\end{array}$ & $\begin{array}{l}\text { RT, } \\
\text { LX }\end{array}$ & $\begin{array}{l}\text { Used as a single drop in the } \\
\text { treatment of jaundice } 15\end{array}$ \\
\hline 33. & $\begin{array}{l}\text { Ricinus } \\
\text { communis L. } \\
\text { (EP33) }\end{array}$ & $\begin{array}{l}\text { Earndi, } \\
\text { Erand, } \\
\text { Diwali, } \\
\text { Diwgi }\end{array}$ & Tree & $\begin{array}{l}\text { Almost } \\
\text { Throughout } \\
\text { year }\end{array}$ & $\begin{array}{l}\text { Cultivated in the } \\
\text { fields for oil } \\
\text { production. }\end{array}$ & SD & $\begin{array}{l}\text { Seed oil is used in dermatosis and } \\
\text { eczema. } 16\end{array}$ \\
\hline 34. & $\begin{array}{l}\text { Synadenium } \\
\text { granti Hook. } \\
\text { f.(EP34) }\end{array}$ & Eronda & Shrub & March-May & Planted along fences & LX & $\begin{array}{l}\text { Latex is applied for wound } \\
\text { healing } 17\end{array}$ \\
\hline
\end{tabular}

Part Used - FT : Fruit, WP : Whole plant, SB : Stem Bark, LX : Latex, SD: Seed, LE : Leaves, EP:Euphrobiaceae

\section{Results and Discussion}

The results of this study survey are presented in Table: 1 and the scientific names of the plant are arranged in alphabet order. The present investigation comprises 34 members of Euphorbiaceae. For each member scientific name, family, local name, part used, method of preparation, administration and aliment treatment has been provided. Tribal communities are using these plants to cure various diseases like diarrhoea, cough, skin disorder, astroinstestinal disorder, asthma, night blindness, scabies, tooth decay, dysentery, snake and scorpion bite, ringworm, headache, jaundice, burn, Gonorrhoea, antiseptic, urinogenital disorder, Bronchitis, Dibetes, Antihelmintic, Wound healing, Ringworm Vermifuge and Laxative. Figure2 illustrates genus wise distrubation of Euphrobiaceae member the order of Euphrobian genus are Euphrobia Acalypha, Chrozophora, Jatropha, Baliospermum, Bridellia, Cicca, Cleidion, Codiaeum, Croton, Embilica, Kirganelia, Mallotus, Micrcoocca and Pedilanthus. During survey, one common thing was observed that a single plant was used for more than one diseases. For example Acalypha hispida, Brume (Haemoptysis, Gastro-intestinal) Respiratory affections, fractures. Toothache and Earache, severe cough associated with bleeding from lung and Diarrhoea) Baliospermum mouthanum (wild) muell-Arg. (Anasarca, dropsy, flatulence, constipation, jaundice, hemorrhoids leprosy, skin diseases, strangury, vesical cacculi, wounds, splenomegaly, anaemi leucoderma, fever and vitiated condition of vata, asthma, bronchitis, vat inflammations, flatulence) and Euphorbia hirta. (Urinary disorder, itches, gonorrhoea Remove warts cure scabies.The leaf of Croton bonplandianum is applied in the trement of typhoid fever by tribal people of North Maharashtra region and our observations are in accordance with earlier antimicrobial activity report made by Jeeshna et al., 2011 against Escherichia coli, Salmonella typhi, Staphylococcus aureus and Bacillus Subtilis. Bark of Jatropha crucus was used by aborigines of investigated part as toxic ingredients and this confirms earlier claim made by Rug and Ruppel, 2000. The whole plant extract of Euphrobia hirta is used as an anti diarrhoeal agent and this confirms earlier report ${ }^{14}$ given by Galves et al, 1993. Fruit of Emblica officinalis, Kirganelia reticulate and Bridelia airyshawii are used as a food material because of it nutritious value and it content of hydrolytic enzyme and many more macro and micro nutrient. The content of this fruits are confirmed by experiments conducted in our laboratory under standard conditions. Information recorded from tribals of North Maharashtra region is more or less parallel to earlier observations about all the plants compiled by us. The most commonly utilized part of plant wasWP(G\%)followed by root and leaf(D\&A\%) respectively, latex(E\%),Bark(F\%),Stem and Seed(B\&C\%) in figer.3. The information generated from the present study about Euphorbian plants used by traditional people needs to be evaluated for proper biochemical analysis with respect to their enzymatic assay, level of toxicity, phytochemical investigations including alkaloid extraction and isolation of along with few clinical trials Phytochemical examination of these plant may lead to development of potential bio- product in the treatment of eye disorders ,for healing of wound skin diseases toothache and many other human aliment .This could help in mass awareness of conservation of such plant to promote ethano medico botany knowledge within the region beside contributing to preservation of such medicinally important species before they are lost forever 


\section{Conclusion}

From the above observation it is evident that Euphorbiaceae family play a significant role in ethnomedicinal and ethnoveterinary system present in this area by contributing 34 plant species .It is also evident that a particular plant used by one aboriginal group to treat a particular disease. Ethanobotany is an ever growing field and form the mainstay in establishing the therapeutic potential and medicinal use of herbs growing in the interior area of India, where as tribal people use plants of that region as medicine.Therefore ,the plants require a thorough investigation of their bio-active compounds for the efficiency reported in different literature.

\section{Acknowledgement}

The authors express thanks to Dr. D.A. Patil, Department of Botany, SSVP's, Dr. P.R. Ghogrey Science College, Dhule who helped us wholeheartedly to identify the plants. We are also thankful to the inhabitants of the surveyed areas for their co-operation and help during field study. Thanks to local medicine men for identifying plants and clarifying medicinal uses.

\section{References}

[1]. Julius T.M. and Patrick V.D. 2011. Why do Euphorbiaceae tick as medicinal plants? A review of Euphorbiaceae family and its medicinal features, (2011). Review J. Med. Plants Resvol. (5) 652-662.

[2]. Tokuoka T, Tobe H 1995. Embryology and systematics of Euphorbiaceae. Lat : a review and prespective. J. Plants Res., 108:97106.

[3]. Seigler DS 1994. Phytochemistry and systematic of the Euphorbiacea, Ann. Mol. Bot. Gard., 81:380-401.

[4]. Appendino G, Szllasi A 1997. Euphorbium: Modern research on its active principle, resiniferatoxin, revives an ancient medicine Life Sci., 60:681-696.

[5]. Gupta B, Rasmi S, Goyal Radha 2007. Therapeutic uses of Euphorbia thymifolia: A Review. Pharmacogn. Rev., 1:299-304

[6]. Brahmam M, 2000. Some ethnomedicinal plants of Akola and Sangamner taluks of Ahmednagar, J Indian Bot Soc, 81 $213-215$.

[7]. Falodun, A Agbakwuru EOP 2004. Phytochemical analysis and laxative activity of Euphorbia heterophylla linn (Euphorbiaceae) Park J. Sci. Res. 47(5) 345-348.

[8]. Kirtikar, K.R. and Bbasu, B.D. 1975. Indian medicinal plants Vol. I-IV, Second Edition M/s Bishan Singh Mahendrapal Singh, New Delhi.

[9]. Chopra, R.N. Nayar, S.L. and Chopra, I.C.1992. Glossary of Indian Medicinal plants CSIR New Delhi.

[10]. Abdel-Fattah MR 1987. The chemical constituents and economic plants of the Euphorbiaceae. Bot.J.Linn. Soc., 94:293-326.

[11]. Okigbo RN, Ahuagasi CL, Amadi JE 2009. Advances in selected medicinal and aromatic plants indigenous to Africa. J. Med. Plants Res., 3L86-89.

[12]. Badgujar S.B. and Mahajan R.T. 2011 Journal of Phytopharmacology. 2(2), 2011, 37-42.

[13]. Galves et al, 1993.

[14]. Mahajan R.T. and Chopda M.Z. 2009. Wound healing plants of Jalgaon District, Maharashtra state, India. Ethnobotanical leaflets; 13:1-32.

[15]. Mahajan R.T. and Badgujar S.B. 2008. Ethanomedicinal values of Laticiferous plants used by tribal people of North Maharashtra, India. Research Link. 55, VII (8):20-25.

[16]. Ignacimuthu, S; Ayyanar,M; Sankarasivaraman, K. (2006) Ethnobotanical investigations among tribes in Madurai district of Tamil Nadu, India. J Ethnobiol Ethnomeducube 2:25.

[17]. Patil D. A. Flora of Dhule and Nandurbar Districts Bishen Singh Mahendra pal Pal Singh,Dehradun U.P.,India 2003.

Figure 1:

Distribution of household remedies $(\%)$ used for various ailments

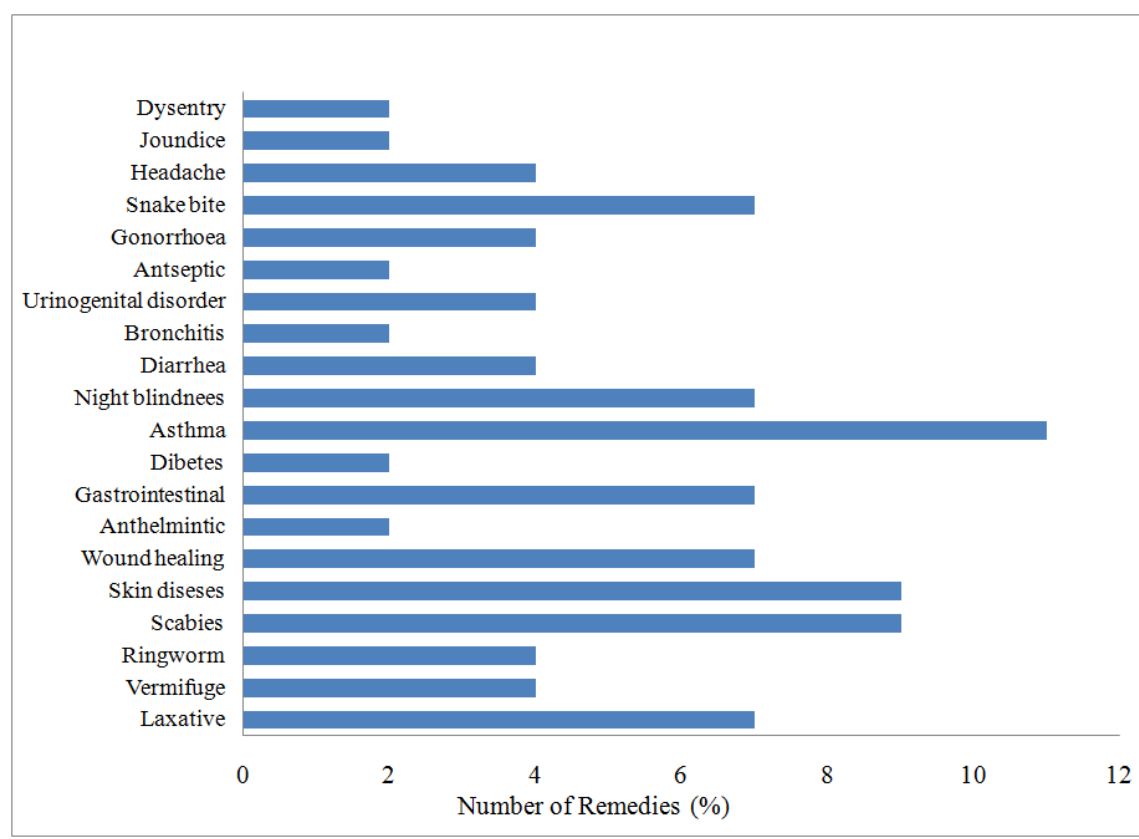

www.iosrjournals.org 


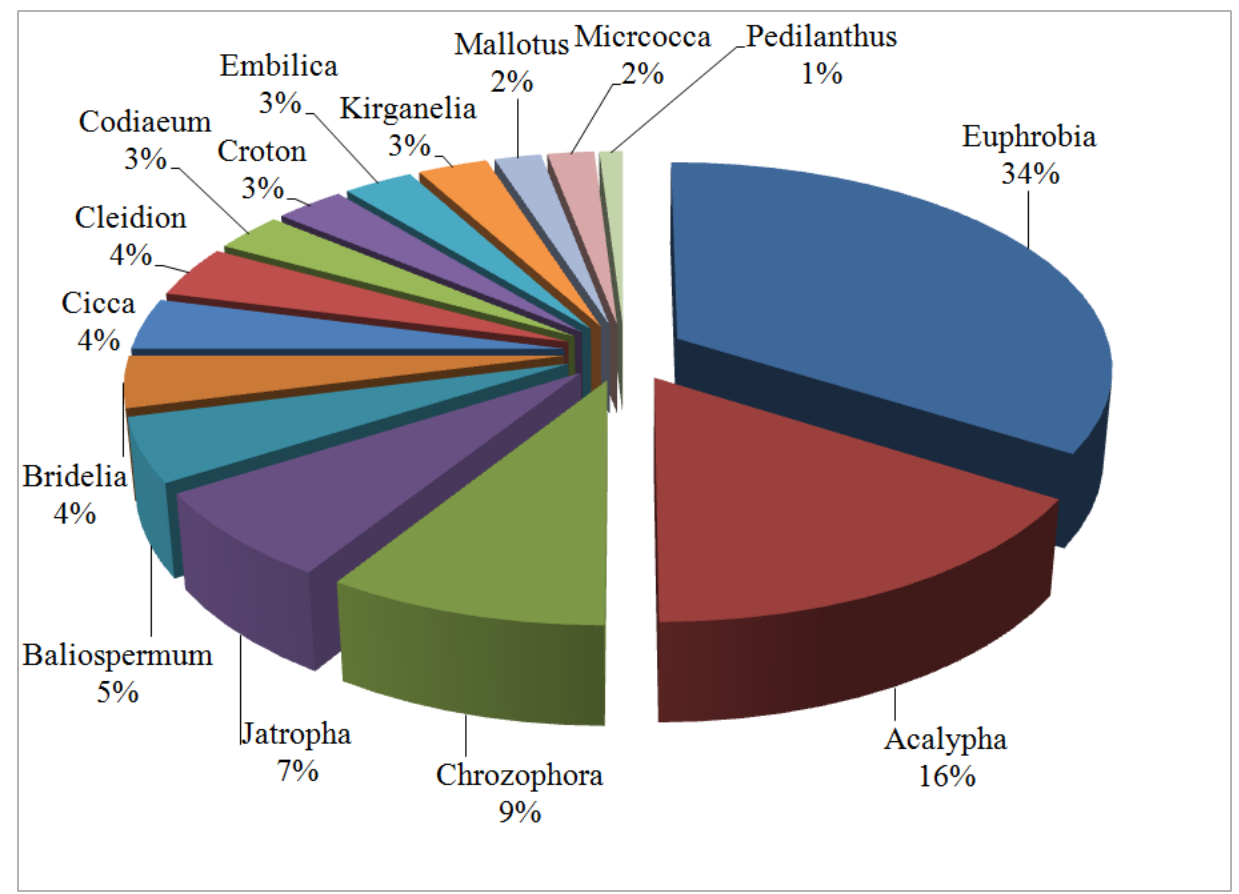

Figure 2: Genus wise distribution of Euphorbian plants occurred in North Maharashtra region of Maharashtra

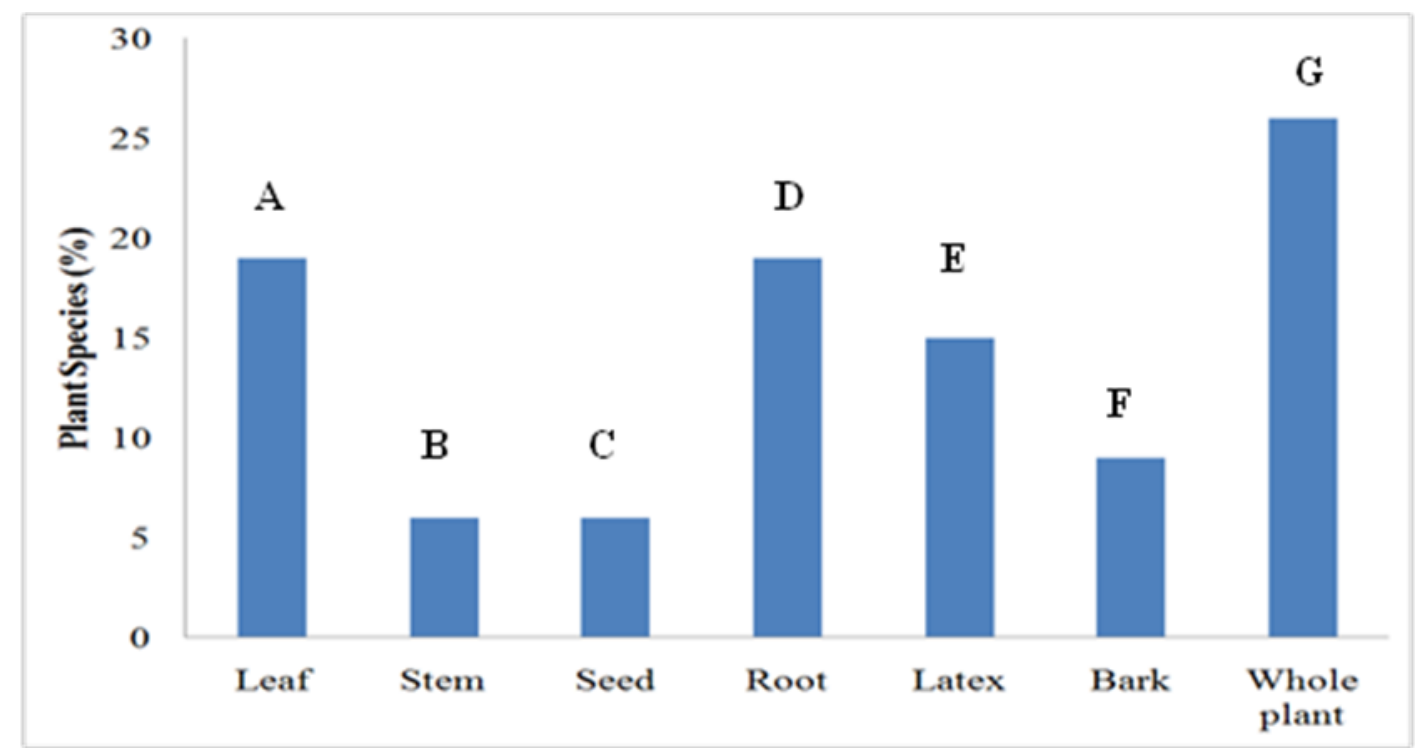

Figure 3: Frequency of plant parts used for preparation of remedies 